\title{
The Perception Of Afghan-American Leaders' Role In Economic Development Efforts In Afghanistan: A Study Of Gender Differences And Repatriation To The Motherland
}

Belal A. Kaifi, Franklin University, USA

Bahaudin G. Mujtaba, Nova Southeastern University, USA

Yan Xie, Nova Southeastern University, USA

\begin{abstract}
The majority of Afghanistan's best educated and experienced generations of workers have become scattered expatriates living throughout the world. This brain-drain has taken place over a thirtyyear period due to continuous violence, tragedy, and war throughout Afghanistan. As such, a rebuilding process now largely depends on the international community. This study of 58 male and 42 female Afghan-American respondents analyzes their perceptions regarding development opportunities in Afghanistan as well as their willingness to take part in the rebuilding process. It appears that there are some differences in the responses of males and females. The younger generation seems to be much more willing to go back and help in the rebuilding process. There seems to be a longevity effect: those who have been away from Afghanistan for a longer period of time are less willing to return for the rebuilding initiatives. Results and implications are presented.
\end{abstract}

Keywords: Afghans, Afghanistan, gender, education, brain drain, dependency, economic development.

\section{INTRODUCTION}

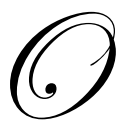

ver the years, the struggle for a unified Afghanistan has become a complex situation to fathom. The combination of Afghanistan's strategic location, colonialism, neocolonialism, tribalism within its region, sub-optimal leadership, and belligerent neighbors has contributed to the many difficulties experienced by its people and has proven to be a recipe for disaster (Mujtaba, 2005b; 2007b). Furthermore, the post 1929 laissez-faire mentality towards education has haunted the Afghan people for decades and has resulted in a lifelong dependency on foreigners who have always had their own hidden agendas of strategically occupying the region (Kaifi, 2008, p. 17). In the late 1800's and early 1900's, the English made three attempts to colonize the country and were unsuccessful. Throughout the 1980's the Russians attempted to occupy Afghanistan. Next, the Pakistan-backed Taliban emerged and enforced their fundamentalist views on Afghans. Today, Americans are in Afghanistan. Many question who will be in Afghanistan tomorrow or the day after.

The power of an educated society is priceless; it makes the country competitive through continuous and sustainable capacity building (Mujtaba, 2005a). Ultimately, it eliminates the intervention of foreigners and creates a unified civil society. Unfortunately, Afghanistan has always looked elsewhere for help throughout its history: India has donated old planes, the Russians built the famous Polytechnic University and Macreyon apartment complexes in Kabul, the French helped create the Istiqlal high school, the Germans helped create the Amani high school, the Arabs donated millions of dollars to the Afghans during the Afghan-Russian war, the American army helped replace 
the Taliban regime, and the list goes on and on. As a result of this long-term foreign assistance and dependence, Afghanistan has regressed and is struggling to provide food and electricity for its people while neighboring countries are developing nuclear arms (Kaifi, 2008, p. 17). In economics, the dependency theory concludes that poverty in developing nations is the result of their dependence on high-income nations, which is precisely the case in Afghanistan. Ultimately, "Dependency theory thus claimed to explain both continued underdevelopment globally and persistence in inequality and class structure within peripheral economies" (Perraton, 2007, p. 32).

\section{DEPENDENCY THEORY AND AFGHANISTAN}

Afghanistan throughout the millennia has been a place of rich culture and a junction of peoples from multiple continents (Mujtaba, 2007b). Despite its diverse history, according to William Wood - the American Ambassador to Afghanistan, "Afghanistan is the most foreign country in the world - It's a ferociously foreign country" (May, 2008). According to the U.S. Commander, Gen. David McKiernan, most people in Afghanistan have been raised during times of constant foreign and civil wars and thus "have been traumatized by violence" (May, 2008). This has led the country to become dependent on the international community for survival and the prospect of a peaceful future. Of course, "Dependency theory concludes that poverty in the developing nations is the result of their dependence on high-income nations" (Tregarthen \& Rittenburg, 2000, p. 675). Influence is exerted over Afghanistan by many other nations. This is a normal occurrence:

Dependency theory holds that the industrialized nations control the destiny of the developing nations, particularly in terms of being the ultimate markets for their exports, serving as the source of capital required for development, and controlling the relative process and exchange rates at which market transactions occur. (Tregarthen and Rittenburg, 2000, p. 675)

Despite much foreign aid, Afghanistan still lacks in many professional and technological fields (Mujtaba, 2005b). This is perhaps normal as well since "the benefits of trade between a rich country and a poor country will go almost entirely to the rich country" (Tregarthen \& Rittenburg, 2000, p. 675). Ahiakpor states that:

Dependency theory is a set of ideas with a strong potential for influencing policy actions in the Third World. Originally developed during the late 1960's to explain the problems of Latin America by scholars working in that region, the theory has attracted a great deal of attention both in the literature and in Third World countries. (1985, p. 535)

Even though the majority of the benefits are going to the richest countries, poor countries do not have many options if they want to live peacefully with the international community. The good news is that "Dependency theory, like Marxian economic analysis, promises prosperity, equity, and justice once the political obstacles to economic transformation have been overcome" (Ahiakpor, 1985, p. 538). In this case, the future does look brighter if the citizens of the developing country educate themselves and become self-reliant key players in the global community. Ultimately, the people of a country must help themselves if they want to prosper and to be key players in the global community. However, it has been suggested that the people of each country must realize that "Capital and technology from the West do not lead to development but can only deepen underdevelopment" (Munck, 1999, p. 58).

Poor countries are often stuck in the cycle of oppression until they are able to put an end to this cycle through entrepreneurship, development and education. According to Perraton,

Dependency theory not only argued that the nature of peripheral countries' insertion into the global economy perpetuated their subordinate status but also that it reinforced domestic inequality with a 'comprador' bourgeoisie unable to play a developmental role leading to the type of capitalist transformation seen historically in Western countries. (2007, p. 32)

Such countries must develop a comparative advantage for themselves to trade with their regional neighbors and globally. Gradually, they must strive for escaping the dependency trap since dependency is said to be a theory of underdevelopment: "Poor countries exiled to the periphery of the world economy could not develop as long as they 
remained enslaved by the rich nations of the center" (Velasco, 2002, p. 44). Long-term dependence cannot be sustained. Dos Santos explains that:

By dependence we mean a situation in which the economy of certain countries is conditioned by the development and expansion of another economy to which the former is subjected. The relation of interdependence between two or more economies, and between these and world trade, assumes the form of dependence when some countries (the dominant ones) can expand and be self-sustaining, while other countries (the dependent ones) can do this only as a reflection of that expansion, which can have either a positive or negative effect on their immediate development. (1970, p. 231)

Tensey and Hyman explain that "Through this world system, advanced nations extract surplus value from underdeveloped nations, thus keeping the latter underdeveloped and condemning them to perpetual class conflicts and oppressive governments" (1994, p. 27).

Dependency can be best converted into sustainable development through equal and speedy education of all citizens of a country. Equal and public access to a speedy education can help avoid the disparity between the upper and lower classes. As stated by researchers, "dependency theory holds that economic development widens the gap between the rich and the poor because most new jobs are for educated middle-class and skilled blue-collar workers rather than for unskilled workers" (Tensey \& Hyman, 1994, p. 31).

\section{THE AFGHAN JOURNEY TOWARD INTERDEPENDENCY}

Independency is part of the journey toward the ultimate goal of living interdependently with the global community. However, over-emphasizing nationalism, culture, and historical literature can certainly lead people of a society to desire absolute independence from the global community. This, however, is not a long-term solution in today's interconnected global community.

In research studies by Mujtaba (2007), the "independent" value was ranked as one of the top five by Afghan professionals. This should be evaluated in how it impacts behavior positively and negatively and the implications involved. The term "Afghan" stands for love, courage, devotion, dignity, commitment, loyalty, and the desire to make sacrifices for one's country and people. Mujtaba (2007) mentions that Afghans have long been committed to being free of outsiders' influence at all costs. This type of patriotism and conditioning towards independence has been weaved into the culture. Afghans need to realize that independency is not the solution to all of the country's challenges, and today's environment requires "interdependent" global relationships with other countries and allies. As a matter of fact, Afghans' desire to live independently is ironically what led to the country's eventual dependence on foreign countries, or donors. This has been the case since the invasion of Afghanistan by the former Soviet Union (Russians) forces (Mujtaba, 2007b). Today's economic productivity and work environment are dependent on an "open system" where people can receive resources from anywhere worldwide and sell them globally, rather than functioning in a "closed system" which requires independency on all fronts. Overall, dependence is especially harmful when the nation is forced to rely upon less-developed countries. "Dependence" must be converted to "independence" and then to "interdependent relationships" globally; in this way, Afghanistan can benefit from certain comparative advantages which are afforded to it through its natural resources.

Unfortunately, the continuous conditioning of "independence" can also lead to ethnocentricity, as well as xenophobic thinking and paradigms. This "surface level" mentality can negatively impact a country who is receiving international assistance in the rebuilding process. High illiteracy rates in the country may be causing this mentality since they cannot perform proper cause and effect analysis due to the lack of knowledge on inductive and deductive reasoning. It appears that the current Afghan government is encouraging capacity building by making literacy a top priority while building the workforce's capacity for more effective decision-making (Mujtaba, 2007d).

High literacy rates, continuous education, vocational training, and equipping the workforce with the right skills to become industrialized are critical elements to Afghanistan's progressive development and growth (Mujtaba, 2007a, 2007b). Such workforce training efforts can accelerate economic development and reduce Afghanistan's heavy dependence on foreign aid. These initiatives also require effective and strategic management. Since no two 
situations are likely to be similar in all variables, it is best to apply effective management and situational leadership skills (Mujtaba, 2007c).

\section{RESEARCH METHODOLOGY}

The main research question focused on Afghans who have been educated in the West and whether they would return to assist Afghanistan with the development process. Another research question focused on whether Afghans felt the need for their country to depend on foreign aid over the next few decades.

The hypotheses for this study are as follows:

1. Afghan male respondents will be more willing to return to Afghanistan to help in the rebuilding process than female respondents.

2. Most Afghan respondents will agree that Afghanistan needs foreign aid in order to become self-sustainable in the coming decades.

3. Afghan respondents who are 40 years of age or older will be more willing than younger respondents to return and rebuild their country.

4. Afghan respondents who have lived in the United States for more than 25 years will be more likely to return to help rebuild Afghanistan than respondents who have been in the U.S. for a shorter time period.

5. Afghan respondents believe that unity among diverse ethnic groups is a key element missing in Afghanistan.

Afghan-Americans who participated in this study completed a survey with 15 questions. All of the participants were educated Afghan-Americans residing in California. Education levels varied from bachelor's degrees to doctorate degrees. The researchers explained that the survey was going to be thoroughly analyzed to determine whether educated Afghans would return to Afghanistan. Participants were informed that the survey answers would eventually be used to help in developing a plan for Afghans to return to Afghanistan and assist with the development process.

The survey instrument was distributed to 100 Afghan-Americans by the first author and all of them were collected upon completion. The surveys were personally distributed to Afghan-Americans at two different Mosques located in the San Francisco, Bay Area. These individuals are representative of expatriate Afghans who could be recruited for repatriation to their motherland for reconstruction and infrastructure development projects. Each participant's education level, gender, ethnicity, age, length of time residing in US, and country of birth was identified in the survey. Education levels were as follows: Bachelors degrees (81), Master degrees (16), and Doctorate (3). Of the 100 participants, 58 were male and 42 were female. There were 52 Pashtuns, 20 Tajiks, 7 Hazaras, 9 Uzbeks, and 12 that were multi-ethnic. Ages ranged from 21-55 years, for those who were not born in the US, length of residency ranged from eight to twenty-nine years. Forty-four of the participants were born in Afghanistan. Furthermore, the survey consisted of multiple choice, as well as yes or no questions. All participants were informed that their participation was anonymous and voluntary. For the average respondent, it took about five minutes to complete the survey, and this short completion time is perhaps another factor in the one-hundred percent response rate.

\section{RESULTS AND ANALYSIS}

The variables are nominal and ordinal; therefore, this study used the Crosstab Chi-Square test to analyze the data. The significance levels were judged from Pearson Chi-Square tables.

The hypotheses analysis results were mixed per the data received from the Afghan respondents currently residing in the United States. Many of the Afghans have already become citizens of the United States and are fully assimilated into their communities. As such, due to their current obligations, it appears that many of them cannot agree to abandon their jobs and children in order to fully commit themselves in the rebuilding process of Afghanistan. However, some generations are more able and willing to assist as the opportunities become available. The results for this study are as follows: 
1. The hypothesis stating that "Afghan male respondents will be more willing to return to Afghanistan to help in the rebuilding process than female respondents" did produce statistically significant results (alpha = 0.013) between male and female respondents. Therefore, this hypothesis is not supported since a significantly higher number of females were willing to go back than males.

2. The hypothesis stating that "Most Afghan respondents will state that Afghanistan needs the assistance of foreigners and they should help in order for the country to become sustainable in the coming decades" did produce statistically significant results (alpha $=0.000)$ between those who were born in Afghanistan and respondents who were born outside of Afghanistan. Those respondents who had been born in Afghanistan all stated that foreigners should assist Afghans in the rebuilding process.

3. The hypothesis stating that "Afghan respondents who are 40 years of age or older will be more likely to return to Afghanistan to help in the rebuilding process than the younger respondents" was not supported $($ alpha $=0.000)$ as the younger generation was more willing to go back than their older counterparts.

4. The hypothesis stating that "Afghan respondents who have lived in the United States for more than 25 years will be more likely to return to Afghanistan to help in the rebuilding process than respondents who have been in the U.S. for fewer years" was not supported (alpha $=0.000)$ since none of the respondents in this group demonstrate a willingness to return in the rebuilding process. However, the majority of those who have lived in the United States for 15 or less years are willing to go back to Afghanistan.

5. The hypothesis stating that "Afghan respondents will believe that unity among diverse people groups is a key element missing in the Afghanistan" was not fully supported as the results were mixed with a majority feeling that unity, modernization and education were key elements missing in the country.

For the purpose of this study, the researchers believe that education is the key to self-sufficiency, modernization, escaping the dependency trap, unity, and individual spirituality. There is a correlation between a developing nation who is dependent on foreign assistance and lower levels of education with high levels of illiteracy. The impact education has on a society is priceless. For example, "females who are educated tend to marry as adults rather than as adolescents. They have fewer children, they have access to important information on health and nutrition, and they have greater opportunities for better wages in the marketplace" (Weatherby et al., 2009, p. 91). Education is the foundation of a harmonious community where people settle their differences through discussion and dialogue as opposed to physical conflict. In the coming paragraphs, some of these elements are more deeply reflected upon.

Education levels. Respondents with different educational levels produced different results. Question seven of the survey asked respondents "Have you traveled to Afghanistan post Afghan-Russian war?" As can be seen from the results presented in Tables 1, 2 and 3, at alpha of 0.053, no significant results were found between levels of education and having traveled back to Afghanistan after the closure of the Afghan-Russian war.

However, as presented in Tables 4, 5, and 6, significant results (alpha < 0.000) were found between education and the respondent's willingness to go back for economic development purposes. This study showed that there was a correlation between education level and willingness to return to Afghanistan for rebuilding endeavors. Those with higher levels of education preferred to stay in the United States compared to those with lower levels of education as these group members were more willing to return.

Table 1 - Crosstab

\begin{tabular}{|c|c|c|c|c|}
\hline & & \multicolumn{3}{|c|}{ Q7 } \\
\hline Count & & 1 & 2 & Total \\
\hline \multirow[t]{4}{*}{ Q1 } & 1 & 20 & 61 & 81 \\
\hline & 2 & 0 & 16 & 16 \\
\hline & 3 & 0 & 3 & 3 \\
\hline & Total & 20 & 80 & 100 \\
\hline
\end{tabular}


Table 2 - Chi-Square Tests

\begin{tabular}{|l|c|c|c|}
\hline & Value & Df & Asymp. Sig. (2-sided) \\
\hline Pearson Chi-Square & $5.864^{\mathrm{a}}$ & 2 & .053 \\
\hline Likelihood Ratio & 9.536 & 2 & .008 \\
\hline Linear-by-Linear Association & 5.172 & 1 & .023 \\
\hline McNemar-Bowker Test &. &. & b $^{-}$ \\
\hline N of Valid Cases & 100 & & \\
\hline
\end{tabular}

a. 3 cells $(50.0 \%)$ have expected count less than 5. The minimum expected count is .60 .

b. Computed only for a PxP table, where P must be greater than 1 .

Table 3 - Symmetric Measures

\begin{tabular}{|c|c|c|c|c|c|}
\hline & & Value & $\begin{array}{l}\text { Asymp. Std. } \\
\text { Error }^{\mathrm{a}}\end{array}$ & Approx. $\mathrm{T}^{\mathrm{b}}$ & Approx. Sig. \\
\hline \multirow[t]{3}{*}{ Nominal by Nominal } & Phi & .242 & & & .053 \\
\hline & Cramer's V & .242 & & & .053 \\
\hline & Contingency Coefficient & .235 & & & .053 \\
\hline \multirow[t]{3}{*}{ Ordinal by Ordinal } & Kendall's tau-b & .238 & .037 & 3.996 & .000 \\
\hline & Kendall's tau-c & .152 & .038 & 3.996 & .000 \\
\hline & Gamma & 1.000 & .000 & 3.996 & .000 \\
\hline Measure of Agreement & Kappa &.$^{\mathrm{c}}$ & & & \\
\hline \multicolumn{2}{|l|}{$\mathrm{N}$ of Valid Cases } & 100 & & & \\
\hline
\end{tabular}

a. Not assuming the null hypothesis.

b. Using the asymptotic standard error assuming the null hypothesis.

c. Kappa statistics cannot be computed. They require a symmetric 2-way table in which the values of the first variable match the values of the second variable.

Table 4 - Crosstab

\begin{tabular}{|c|c|c|c|c|}
\hline \multirow[b]{2}{*}{ Count } & & \multicolumn{3}{|c|}{ Q8 } \\
\hline & & 1 & 2 & Total \\
\hline \multirow[t]{4}{*}{ Q1 } & 1 & 45 & 36 & 81 \\
\hline & 2 & 0 & 16 & 16 \\
\hline & 3 & 0 & 3 & 3 \\
\hline & Total & 45 & 55 & 100 \\
\hline
\end{tabular}

Table 5 - Chi-Square Tests

\begin{tabular}{|l|c|c|c|}
\hline & Value & Df & Asymp. Sig. (2-sided) \\
\hline Pearson Chi-Square & $19.192^{\mathrm{a}}$ & 2 & .000 \\
\hline Likelihood Ratio & 26.340 & 2 & .000 \\
\hline Linear-by-Linear Association & 16.927 & 1 & .000 \\
\hline McNemar-Bowker Test &. &. &.$^{\text {b }}$ \\
\hline N of Valid Cases & 100 & & \\
\hline
\end{tabular}

a. 2 cells $(33.3 \%)$ have expected count less than 5 . The minimum expected count is 1.35 .

b. Computed only for a PxP table, where P must be greater than 1 . 
Table 6 - Symmetric Measures

\begin{tabular}{|c|c|c|c|c|c|}
\hline & & Value & $\begin{array}{c}\text { Asymp. Std. } \\
\text { Error }^{\mathrm{a}}\end{array}$ & Approx. $T^{b}$ & $\begin{array}{c}\text { Approx. } \\
\text { Sig. }\end{array}$ \\
\hline \multirow[t]{3}{*}{ Nominal by Nominal } & Phi & .438 & & & .000 \\
\hline & Cramer's V & .438 & & & .000 \\
\hline & Contingency Coefficient & .401 & & & .000 \\
\hline \multirow[t]{3}{*}{ Ordinal by Ordinal } & Kendall's tau-b & .431 & .052 & 5.356 & .000 \\
\hline & Kendall's tau-c & .342 & .064 & 5.356 & .000 \\
\hline & Gamma & 1.000 & .000 & 5.356 & .000 \\
\hline Measure of Agreement & Kappa &.$^{\mathrm{c}}$ & & & \\
\hline \multicolumn{2}{|l|}{$\mathrm{N}$ of Valid Cases } & 100 & & & \\
\hline
\end{tabular}

a. Not assuming the null hypothesis.

b. Using the asymptotic standard error assuming the null hypothesis.

c. Kappa statistics cannot be computed. They require a symmetric 2-way table in which the values of the first variable match the values of the second variable.

There were significant statistical differences (alpha < 0.00) in response to the question, "Do you think foreigners should help with the development process?" Different levels of education yielded significant viewpoints about whether foreigners (the international community) should or should not help Afghans. Participants with only a bachelor's degree agreed that foreigners should help; those with a master's degree mostly disagreed to the question and would prefer foreigners not to help; doctoral degree respondents all held the viewpoint that foreigners should not help in the development process. The more educated respondents perhaps believe that Afghans are capable of helping themselves without the unwanted influence of foreign governments which often comes with preconditions and hidden agendas.

With regards to how much time it will take until Afghanistan becomes self-sufficient, the results were statistically significant among those with bachelor degrees and those with graduate degrees (alpha $<0.000$ ). Bachelor degree respondents hold a variety of viewpoints on the time range - anywhere from 5 or more years; master and doctoral degree respondents all agree it will take more than 20 years for Afghanistan to be self-sufficient.

When it comes to moving back to Afghanistan, $42 \%$ responded that they would go back to Afghanistan, suggesting that $58 \%$ would not return. Similarly, $90 \%$ of the respondents said that they have not applied for a job in Afghanistan. About $71 \%$ responded that they do not know where to locate jobs in Afghanistan even if they were interested.

When participants were asked "whether they believe that education, Islam, modernization, or unity was missing in Afghanistan," there were statistically significant differences (alpha $<0.000$ ) between respondents with different levels of education. Bachelor degree respondents chose a variety of answers; very few choose unity. However, master and doctoral respondents all chose unity as the primary factor missing among different people groups in Afghanistan.

Gender responses. There were no significant differences in the responses of male and female participants in regards to traveling back to Afghanistan after the Afghan-Russian war. However, a significantly higher number (alpha $=$ 0.013) of male respondents chose not to go back compared to females. With regards to foreign aid, there were no statistically significant differences $($ alpha $=0.248)$ between female and male respondents, who all hold a variety of opinions.

Other variables. There was a significant difference (alpha $<0.000$ ) based on longevity in the United States in relation to traveling back to Afghanistan since the end of the Afghan-Russian war. Most of the respondents that have lived in the US for at least 5 years responded that they have traveled back to their country after the Afghan-Russian 
war. The majority of the respondents, who have lived in the US for at least 15 years, stated that they would not travel back. None of the participants who have lived in the US at least 25 years said that they have traveled back. As a result, longevity as an expatriate decreases the chances of going back to Afghanistan, even for regular traveling to see and visit family and friends. Of course, lack of security in the region may be the sole reason for such results.

Those who have lived in the US at least 5 years responded that they are all willing to go back to Afghanistan and help. However, those who have lived in the US for at least 25 years all responded that they are not willing to go back at this time.

Respondents who have lived in the US for 5 to 15 years all believe that foreigners should help; however, responses of those who have lived in US for more than 25 years varied on this question. Also, those who have lived in the US more than 25 years all said that it will take more than 20 years for Afghanistan to become self-sufficient. While those who have lived in the US for at least five years said that they would move back to help (alpha $=0.000)$, those who have lived in the US for more than 25 years all said that they would not go back to help - at least not at this time since security is still a major concern. As matter-of-fact, the American Broadcasting Corporation's (ABC's) World News on January $2^{\text {nd }}$ of 2009 reported that in the 2008 year more American soldiers lost their lives in Afghanistan than every other year since their involvement in the country in late 2001. Thus, security conditions have gotten worse and this is a major concern for not wanting to return back to Afghanistan under such conditions.

A few respondents (10\%) who applied for jobs in Afghanistan have lived in the US at least 5 years. The respondents who have lived in the US for 15-25 years all said that they have not applied for a job in Afghanistan after 9/11. Those who have lived in the US at least 5 years said that they believe Afghanistan is missing education; those who have lived in US at least 15 years said that they believe Afghanistan is missing education, Islam, and modernization; however, those who have lived in US at least 25 years said that they believe Afghanistan is missing unity.

There were some statistically significant differences with regards to age and traveling back to Afghanistan (alpha $=0.000)$. Only some of the respondents $(20 \%)$ between the ages of 18-28 have traveled back; however, out of those who are between the ages of 29-65, none have traveled back to Afghanistan after the Afghan-Russian war. On the issue of returning to help rebuild Afghanistan, the older age groups are more reluctant while the younger age group is more optimistic. Similarly, most of the younger (18-39) respondents believe that foreigners should help $($ alpha $=0.000)$, while the older $(40-65)$ respondents suggest that foreigners should not help. For the age groups between 18-28 years of age, some of them have applied to go back to Afghanistan. Perhaps various agencies can recruit skilled workers from this generation of Afghan-Americans as they are more willing to go back for the economic development of Afghanistan. Interestingly, none of the other age groups have applied for jobs in Afghanistan. Of course, the first generation of Afghan expatriates have probably accepted the fact that Afghanistan will never be the same and are probably busy adapting to their new home (US) and are unwilling to make another drastic move at this stage in their life, perhaps until their home country becomes more secure.

On the issue of what is currently lacking in Afghanistan, different age groups responded as follows:

1. Age 18-28: Afghanistan is missing education and Islam.

2. Age 29-39: Afghanistan is missing Islam, modernization or unity.

3. Age 40-65: Afghanistan is missing unity. This opinion is shared by people with higher education degrees as well.

There were statistically significant differences $($ alpha $=0.000)$ between the responses of those who were born in Afghanistan and those who were born outside of it. Those who were born in Afghanistan all responded that they would go back to help. However, the majority of those who were not born in Afghanistan responded that they would not go back to help in the rebuilding process. Also, those participants who were not born in Afghanistan have not applied for a job in Afghanistan; furthermore, the same group also believes that Afghanistan is primarily missing modernization and unity; a few think it is also lacking Islamic values. 
On the issue of ethnicity, only Pashtun respondents have traveled to Afghanistan after the Afghan-Russian war. It must be mentioned that the major ethnic group in Afghanistan are the Pashtuns and the majority of the participants of this survey were Pashtun. The majority of the Pashtuns indicated that they are willing to go back. Similarly, a few Tajiks indicated the same. On the issue of what is currently missing in Afghanistan, responses based on ethnicity were as follows:

- $\quad$ Pashtun: Education, then Islam.

- $\quad$ Tajik: Modernization, then Islam.

- Hazara: Modernization, then Unity.

- $\quad$ Uzbek and Multi-Ethnic Respondents: Unity.

\section{IMPLICATIONS AND REFLECTIONS}

The majority of the respondents believe that education, modernization, and unity are missing in Afghanistan. If this is the case, then perhaps people can become united around their common spiritual faith. Furthermore, the main focus should be on public education since education is emphasized in all major religions. This will ultimately lead to modernization and development.

Education is the key to the development of a country and its capacity to develop infrastructure. As such, administrators and officials must do what they can to provide an environment where people are encouraged and supported to complete their educational dreams by earning advanced degrees nationally or internationally (Mujtaba \& Scharff, 2007). Educational opportunities for the local community as well as programs to encourage the return of Afghan expatriates will alleviate the brain-drain challenges facing the country.

It is fortunate to see that educated and visionary individuals both inside and outside of the country seem to be working hard to pave the way toward a brighter Afghanistan. Mujtaba (2007a) mentions that while having an advanced degree on the part of each official is not a prescription or solution for all of Afghanistan's current and prospective challenges, it is an important initial step forward toward the development of each person's capacity to produce knowledge, make better decisions, and live in a more qualitative manner. It is also promising to see that the Constitution of Afghanistan has made the credentials of higher education a required consideration for selecting ministers (Mujtaba, 2007a). Such requirements will certainly encourage learning, creativity, and continuous pursuit of knowledge among all those who want to serve Afghanistan peacefully through education. Certainly, the strenuous work of all individuals must be duly acknowledged and their consultative services should be sought where relevant. It must also be considered that warfare knowledge and experience may not always transfer well to other jobs where the future of a country is at stake. While one might be perfectly prepared to manage and lead a group of people militarily against invaders, such skills do not always translate into leading educational, business, and professional initiatives. As such, professional certification and higher levels of education in various fields are prerequisites if one is to appropriately lead Afghans toward productivity and self-reliance and away from dependency.

Therefore, Afghan elders and war veterans should encourage the youth to seek knowledge and to become more competitive both locally and globally. However, there might be cases when Afghan elders, as effective situational leaders, may have to humbly and voluntarily step aside to let the most knowledgeable person lead. Educational qualifications and relevant experience should be the criteria for choosing who will be best suited to make the people, the department, and the country of Afghanistan more economically competitive (Mujtaba, 2005a \& 2007b). Hiring based on skill and educational level will filter out the nepotism practices which have been widespread in Afghanistan. As explained by Cavico and Mujtaba (2008, 2009), ethical hiring practices are critical for human resource managers and government officials if organizations and countries are to be seen as socially responsible in their communities. The key for Afghan officials is to seek, recruit and retain such individuals by providing them with the right incentives and work environment. For example, a doctor might be a very wise person, but he or she cannot be a good engineer without an engineering license and relevant work experience. As a result, the doctor should perform jobs that are in his or her field rather than accepting positions that require certain engineering skills. Afghans should be familiar with this concept because the most knowledgeable and educated clergyman becomes the mosque leader, not necessarily the eldest member. Official rank, intelligence, level of wealth and one's overall status in the community does not necessarily determine who leads the prayer in the mosque. The 
right person is the one who has acquired the most knowledge of Islamic theology and law and has advanced spiritually by practicing this knowledge. Mujtaba (2007b) explains that Afghanistan needs the right individuals in the right jobs if they are to be a "relevant player" in the international community and successfully compete in today's global economy. Thus, the most qualified individuals should be placed in specific positions and must be given the opportunities to serve their country in the best way possible. The same concepts and principles apply to the selection of ministers and government leaders: the most qualified person must be selected for the job. Afghan leaders are being advised to comply with the Constitution which requires the consideration of advanced education for the selection of ministers. Besides having the right education, the right candidates should be continuous learners since new information is being generated at a rapid pace. Constant learning is imperative for effective management and leadership regardless of one's country or work location.

\section{CONCLUSION}

This study surveyed Afghan-Americans and analyzed their perceptions regarding development opportunities in Afghanistan as well as their willingness to take part in the rebuilding process. The article discussed differences in the responses of males and females as well as different ethnic and generational groups. The younger generation seems to be much more willing to go back and help in the rebuilding process. Furthermore, those who have been away from Afghanistan for a longer period of time are less willing to return, while those with shorter residencies in the US are more willing.

Future studies can look into larger samples of Afghans in the United States, as well as in Europe, Asia, and Russia to assess their perceptions on the same issues.

\section{AUTHOR INFORMATION}

Belal A. Kaifi earned a doctoral degree from the University of San Francisco where he studied Organization and Leadership in the School of Education. Belal is the Director of the General Education Program at Western Career College and also teaches undergraduate and graduate level courses in Business Administration and Global Issues at Franklin University. Belal can be reached at: belalkaifi@yahoo.com.

Bahaudin G. Mujtaba is an Associate Professor of Management and International Management at Nova Southeastern University's H. Wayne Huizenga School of Business and Entrepreneurship in Fort Lauderdale, Florida. Bahaudin has worked as an internal consultant, trainer, and management development specialist as well as retail management in the corporate arena for over 16 years. Bahaudin has been teaching business courses and professional development workshop both nationally and internationally (United States, Bahamas, Jamaica, Grenada, St. Lucia, Thailand, Afghanistan, and Brazil) since 1996. Bahaudin is the author and co-authors of several books in the areas of management, business ethics, leadership, and international management. Bahaudin can be reached through email at: mujtaba@nova.edu.

Yan Xie is currently a doctoral student majoring in information system management at Nova Southeastern University's H. Wayne Huizenga School of Business and Entrepreneurship in Fort Lauderdale, Florida. Her area of expertise is in information systems and knowledge management practices. Yan Xie can be reached at xyan@ nova.edu or olivebirdfly@gmail.com.

\section{REFERENCES}

1. Ahiakpor, J. (1985). The success and failure of dependency theory: the experience in Ghana. International Organization, 39 (3), 535-552.

2. Cavico, F. J. \& Mujtaba, B. G. (2009). Business ethics: The moral foundation of leadership, management, and entrepreneurship ( $2^{\text {nd }}$ edition). Pearson Custom Publications. Boston, United States.

3. (2008). Legal challenges for the global manager and Entrepreneur. Kendal Hunt Publishing Company. United States.

4. $\quad$ Dos Santos, T. (1970). The structure of dependence. American Economic Review, 60(2), 231-236.

5. May, C. D. (2008). Taliban not sentimental. The Gainesville Sun, 9A, September 29, 2008. 
6. Kaifi, B.A. (2008). The power of education in international economic development. Sitara Magazine, 1(5), 16-17.

7. Mujtaba, B. G. (2007a). The ethics of management and leadership in Afghanistan (2 ${ }^{\text {nd }}$ edition). ILEAD Academy. Davie, Florida USA.

8. (2007b). Afghanistan: Realities of war and rebuilding (2 $2^{\text {nd }}$ edition). ILEAD Academy, LLC, Davie, Florida; United States.

9. _ (2007c). Situational leadership for developing a productive culture from ground zero in Afghanistan. In the Global Economy: Challenges in developing and transition economies; edited by Mina Baliamoune-Lutz, Alojzy Z. Nowak, and Jeff Steagall; volume 2, pages 210-230. ISBN: 978-83-89069-207. Warsaw-Jacksonville, United States.

10. _ (2007d). Empowering the workforce to deliver superior value through the development of a customer-oriented culture in developing countries. In the Global Economy: Challenges in Developing and Transition Economies; edited by Mina Baliamoune-Lutz, Alojzy Z. Nowak, and Jeff Steagall; volume 2, pages 339-372. ISBN: 978-83-89069-20-7. Warsaw-Jacksonville, United States.

11. (2005a). Market-based leadership skills for public and private sector capacity development in Afghanistan. Society of Afghan Engineers Journal, 2(1), pp. 39-52.

12. (2005b). Management and Leadership Developments in Afghanistan: An Interview with Sayed Tayeb Jawad, Afghanistan's Ambassador to the United States. Journal of Applied Management and Entrepreneurship. (10)4, pp. 81-92.

13. \& Scharff, M. M. (2007). Earning a doctorate degree in the $21^{\text {st }}$ century: Challenges and joys. ILEAD Academy Publications; Florida, USA.

14. Munck, R. (1999). Dependency and imperialism in the new times: A Latin America perspective. The European Journal of Development Research, 11(1), 56-74.

15. Perraton, J. (2007). Evaluating Marxian contributions to development economies. Journal of Economic Methodology, 14(1), 27-46.

16. Tregarthen, T., \& Rittenburg, L. (2000). Economics. NY: Worth Publishers.

17. Tensey, R. \& Hyman, M. (1994). Dependency theory and the effects on advertising by foreign-based multinational corporations in Latin America. Journal of Advertising, 23(1), 27-42.

18. Velasco, A. (2002). Dependency theory. Foreign Policy, 133, 44-46.

19. Weatherby, J.N., Arceneaux, C., Evans, E.B., Long, D., Reed, I., \& Novika-Carter, O.D. (2009). The other world: Issues and Politics of the Developing world ( $8^{\text {th }}$ ed). NY: Pearson. 


\section{Appendix - Afghan-American Perception Survey}

1. What is your highest level of education?
A) Bachelors,
B) Masters,
C) Doctorate

2. Are you male or female?
A) Male,
B) Female

3. How long have you lived in the USA?
A) At least 5 years,
B) at least 15 years,
C) at least 25 years

4. How old are you?
A) 18-28 years of ago,
C) 40-50 years of age,
B) 29-39 years of age
D) 51-65 years of age

5. Were you born in Afghanistan?
A) Yes,
B) No

6. What ethnicity are you?
A) Pashtun,
B) Tajik,
C) Hazara,
D) Uzbek,
E) More than one

7. Have you traveled to Afghanistan post Afghan-Russian war?
A) Yes,
B) No

8. Would you like to go back to Afghanistan to help with the development process?
A) Yes,
B) No

9. Do you think foreigners should help with the development process?
A) Yes,
B) No

10. How much longer do you think until Afghanistan becomes self-sufficient?
A) $0-5$ years
B) 6- 10 years
C) 11-20 years
D) more than 20 years

11. Would you ever move back to Afghanistan?
A) Yes,
B) No

12. Have you applied for a job in Afghanistan post 9/11?
A) Yes,
B) No

13. Do you know where to locate jobs for Afghanistan?
A) Yes,
B) No

14. Has any of your family members returned to Afghanistan for work purposes?
A) Yes,
B) No

15. Which of the following is missing the most in Afghanistan?
A) Education,
B) Islam,
C) Modernization,
D) Unity 